$\begin{array}{ll}\text { Abstracta Iranica } & \begin{array}{l}\text { Abstracta Iranica } \\ \text { Revue bibliographique pour le domaine irano-aryen }\end{array} \\ & \text { Volume } \mathbf{3 7 - 3 8 - 3 9} \text { | } 2018 \\ \text { Comptes rendus des publications de 2014-2016 }\end{array}$

\title{
Matt Waters. Ancient Persia. A Concise History of the Achaemenid Empire, 550-330 BCE
}

\section{Astrid Nunn}

\section{(2) OpenEdition}

\section{Édition électronique}

URL : http://journals.openedition.org/abstractairanica/42568

DOI : 10.4000/abstractairanica.42568

ISBN : 1961-960X

ISSN : 1961-960X

Éditeur :

CNRS (UMR 7528 Mondes iraniens et indiens), Éditions de l'IFRI

Référence électronique

Astrid Nunn, "Matt Waters. Ancient Persia. A Concise History of the Achaemenid Empire, 550-330 BCE », Abstracta Iranica [En ligne], Volume 37-38-39 | 2018, document 10, mis en ligne le 10 mars 2018, consulté le 28 septembre 2020. URL : http://journals.openedition.org/abstractairanica/42568 ; DOI : https://doi.org/10.4000/abstractairanica.42568

Ce document a été généré automatiquement le 28 septembre 2020

Tous droits réservés 


\title{
Matt Waters. Ancient Persia. A Concise History of the Achaemenid Empire, 550-330 BCE
}

\author{
Astrid Nunn
}

\section{RÉFÉRENCE}

Matt Waters. Ancient Persia. A Concise History of the Achaemenid Empire, 550-330 BCE. Cambridge University Press, New York, 2014, 252 p. ISBN-13: 978-0521253697

1 Plusieurs ouvrages de synthèse sur l'empire achéménide ont paru ces dernières années (voir ici Oxford Handbook of Ancient Iran). Mais leur spécialisation requiert que les chapitres soient écrits par plusieurs auteurs. La synthèse présentée ici est relativement courte et d'une seule plume.

2 L'A. a organisé son introduction en 11 chapitres et un épilogue. Il présente d'abord les multiples sources écrites quelle que soit leur langue. Les quatre chapitres suivants s'attachent à l'origine des Mèdes, à celle des Perses et à l'émergence de Cyrus ainsi qu'au règne de Cambyse et de Darius I. Les grandes questions sont replacées dans le contexte plus large de l'histoire proche-orientale englobant par exemple les Elamites, les Assyriens, la Babylonie et l'Anatolie. Les chapitres suivants sont moins axés sur les évènements politiques que sur les institutions royales et sociales, la cour, l'administration, l'économie, le monnayage, les capitales et la religion sous les règnes de Darius I et Xerxès I. Les chapitres 9 à 10 traitent des derniers rois achéménides et des conflits e. a. avec la Grèce. Le chapitre 11 enfin a pour sujet l'ascension des Macédoniens et de la conquête d'Alexandre le Grand, due plus à la capacité de la nouvelle dynastie grecque qu'à la décadence perse.

3 Ce livre fort lisible offre une véritable introduction et une synthèse de l'état actuel des connaissances. Il sera néanmoins encore plus utile aux historiens qu'aux archéologues. 
La parcimonie des plans et illustrations est vraisemblablement plus due à la volonté de la maison d'édition qu'à celle de l'A.

\section{AUTEURS}

\section{ASTRID NUNN}

Université de Munich 